Rok XVI (2021) | 2 (32) | S. 237-244

https://doi.org/10.12797/LV.16.2021.32.19

Licencja: CC BY-NC-ND 4.0

Kinga Tutak • ()

Uniwersytet Jagielloński, Kraków

kinga.tutak@uj.edu.pl

\title{
O RACHUNKU SUMIENIA JAKO ZADANIU TKUMACZA KRYSTYNY PISARKOWEJ
}

Słowa klucze: Krystyna Pisarkowa, Rachunek sumienia jako zadanie tłumacza, Walter Benjamin, teksty spowiedzi z XIV-XVI w.

Keywords: Krystyna Pisarkowa, Rachunek sumienia jako zadanie tłumacza, Walter Benjamin, texts of confessions from the 14th-16th centuries

Formuła lingvariowych Przypomnień - od tego roku Przypomnień $i$ inspiracji - jest na tyle szeroka, że w artykule mogą się pojawić wątki autobiograficzne. Od nich zatem rozpocznę ten tekst. Otóż najpierw jako doktorantka w Instytucie Polonistyki UJ, później już jako nauczyciel akademicki uczęszczałam na wykłady prof. Krystyny Pisarkowej, która nota bene zrecenzowała mój pierwszy artykuł naukowy dotyczący składni (Tutak 20oo), opublikowany w „Języku Polskim”. Bacznie śledziłam wszystkie anonse informujące o prelekcjach K. Pisarkowej i dzięki temu mogłam wysłuchać wykładów poświęconych rachunkowi sumienia i spowiedzi. Z charakterystycznym błyskiem w oczach prof. K. Pisarkowa mówiła o spowiedzi jako całokształcie aktów myśli i mowy, gdy grzesznik świadomie i dobrowolnie ujawnia swoje złe uczynki i okoliczności towarzyszące złym postępkom, a także wyraża skruchę, wstyd i żal przed innym człowiekiem - kapłanem, ale w obliczu Boga. Badaczka podkreślała, że w tekstach starożytnych oraz średniowiecznych wyznań grzechów rozpoznajemy elementy autobiografii (Pisarkowa 2012: 12) - tak jest w Wyznaniach św. Augustyna z przełomu IV i V w. czy w Księdze śpiewów żałobliwych św. Grzegorza z Nareku $\mathrm{z}$ końca X w. Dla mnie był to bardzo cenny trop, ponieważ zajmowałam się wówczas 
piśmiennictwem osobistym. Do tego wątku badawczego, tzn. do związku rachunku sumienia $\mathrm{z}$ autobiografią, jeszcze powrócę w dalszej części niniejszego artykułu, w tym miejscu natomiast chciałam podkreślić, że przedmiotem mojego zainteresowania nie będzie tu rachunek sumienia jako konkretna forma wypowiedzi wpisana w dyskurs religijny. Temu zagadnieniu były poświęcone artykuły Marii Wojtak (2007a, 2007b) i Lucyny Wardy-Radys (2009) ${ }^{1}$. Spróbuję zrekonstruować sposób, w jaki prof. K. Pisarkowa postrzegała spowiedź i rachunek sumienia, i w tym celu posłużę się własnymi notatkami z prelekcji oraz książką Rachunek sumienia jako zadanie tłumacza (Pisarkowa 2012), która ukazała się w krakowskiej oficynie Petrus dwa lata po śmierci autorki. Na pewno nie uda mi się poruszyć wszystkich wątków zaproponowanych przez K. Pisarkową, ponieważ Jej opus posthumum to pogłębiona analiza rozmaitych tekstów mistrzów życia duchowego: historycznych, poetyckich (Wisławy Szymborskiej i Czesława Miłosza), filozoficznych (św. Augustyna, św. Grzegorza czy Jeana Leclercqa). Ważne i niezwykle cenne jest to, że w tej analizie K. Pisarkowa nie wypowiada ostatniego słowa, ale pozostawia miejsca niedookreślenia ${ }^{2}$, które może i powinien uzupełnić czytelnik. Tym samym autorka książki wchodzi w dialog z odbiorcą, ta interakcyjność tkwi w strukturze tekstu, w sposobie argumentowania, nawet $w$ doborze cytatów, a jej sygnałami są różne środki (typo)graficzne, jak: podkreślenia lub wytłuszczenia fragmentów tekstu oraz znaki interpunkcyjne - wykrzyknik (także zwielokrotniony) w tekście głównym i w wypowiedziach parentetycznych, pytajnik oraz wielokropek ${ }^{3}$. Na taki indywidualny styl Uczonej zwróciła uwagę Janina Labocha, która w artykule z 2012 r. pisała o innej pracy K. Pisarkowej:

1 Maria Wojtak wskazuje na trzy formy przekazu rachunku sumienia: 1) w oficjalnych dokumentach Kościoła; 2) w opracowaniach teologicznych, liturgicznych i katechetycznych; 3) w modlitewnikach jako konkretna realizacja wykorzystywana przez wiernych (Wojtak 2007a: 289-290, 2007b: 105). Analizie genologicznej i aksjologicznej zostały poddane teksty wydawane od drugiej połowy XX w. do współczesności. Również Lucyna Warda-Radys (2009) bierze pod uwagę teksty XX-wieczne skierowane do dzieci.

2 W rozumieniu Romana Ingardena (1988).

3 Por. „Bo kazanie bywało, jak uświadamia Leclercq, już wtedy mówione i odczytywane; przepisywane, i nie... przepisywane. Ten gatunek był instytucją!” (Pisarkowa 2012: 28); „Wybrane fragmenty Stów Grzegorza ilustrujące problemy żywe w rachunkach Księgi dowodzą, że ich zawartość i sens zderzają się z jego metajęzykowym, ale słownym sformułowaniem tego, co wiadome (pod)świadomości” (ibid.: 206); „Walter Benjamin (1892-1940), myśliciel, pisarz niemieckojęzyczny pochodzenia żydowskiego, wyemigrował do Francji (1933); zagrożony ekstradycją (Gestapo!), zginął śmiercią samobójczą w Hiszpanii [...]” (ibid.: 222, przypis 5); „Spowiadać się więc miała królewna ze wszystkich grzechów powszednich, śmiertelnych, jawnych, tajemnych, własnych i cudzych [!!!], także tych, których nie pamięta, i tych, których nie uważa za grzech [...]” (ibid.: 141); „W świetle nowelizacji przepisów ortograficznych, bo dozwalają wyjątkowo pisownię rozdzielną nie »jeśli tego wymaga intencja nadawcy«, dodatkowy problem dla teorii przekładu, bo któż zna wszelką intencję nadawcy?" (ibid.: 223, przypis 7). 
Liczne przykłady wyekscerpowane z badanych tekstów, które wymagają od czytelnika książki nie tylko przeczytania, ale również przemyśleń i głębokiej analizy według instrukcji i wskazówek autorki pracy, stawiają nas czytelników przed koniecznością wykazania się umiejętnością aktywnej postawy odbiorczej. Przyjmując taką postawę, znajdziemy w książce Składnia rozmowy telefonicznej niezwykle cenne źródło inspiracji badawczych (Labocha 2012: 142).

Warto w tym miejscu dokonać pewnego uściślenia bibliograficznego. Otóż w tomie prac ofiarowanych prof. K. Pisarkowej zatytułowanym Anabasis z 2003 r. została zamieszczona bibliografia prac Uczonej z lat 1992-2002. Ostatni segment tej listy publikacji to zapowiedzi wydawnicze $W d r u k u$, a wśród nich jako 296. opracowanie znalazł się Rachunek sumienia jako zadanie tłumacza z lokalizacją: $w$ Księdze referatów konferencji orientalistycznej, 20-21 V 2002 r. (Bobrowski 2003: 13). Rzeczywiście, artykuł ukazał się jeszcze w 2002 r. w 24 tomie „Prac Komisji Orientalistycznej” Polskiej Akademii Nauk Języki orientalne w przekładzie (Pisarkowa 2002).

Zarówno w tytule artykułu, jak i w tytule książki został zarysowany związek między rachunkiem sumienia i przekładem, związek, który domaga się komentarza, ponieważ, jak czytamy w nocie wydawniczej na czwartej stronie okładki monografii, „może na pierwszy rzut oka zaskakiwać”. Spróbuję zatem wyjaśnić, w jaki sposób K. Pisarkowa rozumie rachunek sumienia, bo jest to rozumienie wykraczające poza tę wykładnię, którą znajdziemy w Katechizmie Kościoła Katolickiego. W tym tak ważnym dla katolików dokumencie podkreśla się, że poprzez rachunek sumienia może się dokonać nawrócenie (KKK, punkt 1435), czyli „powrót do życia zgodnego z nakazami wiary” (WSJP PAN). Przypieczętowaniem tego aktu jest przyjęcie sakramentu pokuty i pojednania, tzn. przystąpienie do spowiedzi. Jak czytamy w KKK, dzięki spowiedzi człowiek patrzy w prawdzie na popełnione grzechy, bierze za nie odpowiedzialność, a przez to na nowo otwiera się na Boga i na komunię Kościoła, by umożliwić nową przyszłość (KKK, punkt 1455). K. Pisarkowa traktowała spowiedź, a właściwie spowiadanie się, jako ważny i świadomy zwerbalizowany akt wykonawczy, który jest jednocześnie rozmową z Istotą najwyższą (Pisarkowa 2012: 6). Kapłan spowiednik pełni funkcję pośrednika w komunikacji z Bogiem. Jak podkreślała Badaczka, nie znamy jednak spowiedzi - poza spowiedziami własnymi - bo są objęte tajemnicą (ibid.: 51). Czy mamy zatem dostęp do rachunku sumienia poprzedzającego spowiedź? Warto zwrócić uwagę na dwa wymiary tego złożonego aktu. I tak rachunek sumienia to energeia, działanie rewidujące pamięć człowieka i jego lojalność wobec Boga. Grzesznik w myśli czy wręcz w mowie wewnętrznej przypomina sobie, odtwarza, porządkuje, wreszcie wyznaje swoje złe postępki. Stanowią one wykroczenia przeciw prawu Boskiemu, które w Ewangelii według św. Marka zostaje sprowadzone do największego przykazania: „Będziesz miłował Pana Boga swego całym swoim sercem, całą swoją duszą, całym swoim umysłem i całą swoją siłą. [...] Będziesz miłował swego bliźniego jak siebie samego" (Mk 12, 30-31, cyt. za: BT: 1274). Rachunek sumienia jako działanie rozpoczyna się wprawdzie w dyskur- 
sie wewnętrznym (Pisarkowa 2012: 59), ale domaga się translacji ${ }^{4}$, przekładu tajnej prawdy o grzechu czy grzechach na język naturalny, bo - jak pisze K. Pisarkowa owa werbalizacja jest istotnym i najtrudniejszym krokiem przybliżającym do wyzwolenia (ibid.: 62). Takie jest główne przesłanie pracy o rachunku sumienia jako zadaniu tłumacza w rozumieniu Waltera Benjamina (1923/2011) ${ }^{5}$ główne, ale nie jedyne, K. Pisarkowa zwraca bowiem uwagę na drugi wymiar czy aspekt aktualizacji rachunku sumienia: rachunek sumienia jako ergon, wytwór, konkretny gatunek użytkowy, czyli pierwotny w ujęciu Michaiła Bachtina, który jednak może podlegać literackiej transformacji czy mutacji (Wilkoń 2001: 77). K. Pisarkowa uwzględnia zarówno dawne penitencjały, czyli katalogi grzechów, wraz z zachowanymi tekstami spowiedzi z XIV-XVI w., jak i Wyznania św. Augustyna, Księgéspiewów żałobliwych św. Grzegorza z Nareku czy poemat Miłosza Orfeusz i Eurydyka z 2002 r.

Postaram się teraz uzupełnić - przynajmniej częściowo - miejsca niedookreślenia w analizie zachowanych tekstów historycznych spowiedzi polskich zamieszczonych w książce na stronach od 122 do 137 . Nie wszystkie są kompletne, tylko dwa teksty z początku XV i XVI w. zawierają pełną ramę tekstową z formułą inicjalną i finalną zamkniętą modlitewną aklamacją Amen. W formule inicjalnej nadawca zostaje przywołany najczęściej jako ja grzeszny człowiek, natomiast w tekście głównym ujawnia się poprzez odpowiednie zaimki i formy werbalne. Trudno tu zresztą mówić o nadawcy, należałoby raczej wprowadzić za M. Wojtak (2019:33) pojęcie roli illokucyjnej nadawcy, w którą wchodzą penitenci uczestniczący w spowiedzi wspólnotowej lub indywidualnej. Właśnie w tekście spowiedzi nr 1 z końca XIV w. występuje nadawca zbiorowy - my grzeszni ludzie. Tu za K. Pisarkową warto wyjaśnić, że tradycja spowiedzi od starożytności chrześcijańskiej do średniowiecza zakładała powszechność, „publiczność” pokuty poprzez wspólnotowe wyznanie grzechów i modlitwę, od XV w. według wzorca powtarzanego za kapłanem, ze wstawienniczym kajaniem się i odpowiedzialnością za cudze grzechy włącznie. Reliktem we współczesnej liturgii mszy jest odmawiany przez wszystkich wiernych akt pokuty o incipicie Spowiadam się Bogu wszechmogacemu, który według nauczania Kościoła katolickiego gładzi grzechy powszednie. Stopniowe utajnianie doprowadziło do spowiedzi indywidualnej (od XVII w. stosowano stuchalnice, czyli konfesjonał) i wreszcie do surowego nakazu tajemnicy spowiedzi. Stąd źródła konfliktów politycznych, zagrożenia dla spowiedników (Pisarkowa 2012: 57-58), a w państwie autorytarnym,

4 W artykule z 2002 r. Krystyna Pisarkowa (2002: 58) porównała dzieło „translacji” z przenoszeniem relikwii świętego z miejsca, w którym się odbył obrzęd pogrzebu, do innego kościoła, gdzie wykonywano oficjum.

5 K. Pisarkowa zaproponowała autorski przekład eseju Waltera Benjamina z 1923 r. „dla zintensyfikowania kontaktu z oryginałem" (Pisarkowa 2012: 146). Pomiędzy akapitami pojawiły się krótkie komentarze tłumaczki (por. ibid.: 146-159). 
komunistycznym spowiedź jako narzędzie inwigilacji, jak pokazuje Ivan Ostrochovský w filmie Studzy z $2020 \mathrm{r}$.

Powróćmy do tekstów spowiedzi. Formuła inicjalna zawiera czasownik performatywny w 1. os. lp. lub lm., który konotuje grupę nominalną (rzadziej przyimkową) w dopełniaczu: kaje się mych wszech grzechow; spowiadam się mych wszyćkich grzechow lub s moijch (sic) wszystkich grzechow, także w połączeniu szeregowym spowiadam się i winna się dawam moich wszystkich grzechow.

Czasownik performatywny otwiera również miejsce dla grupy nominalnej w celowniku odpowiadającej odbiorcy (częściej odbiorcom) spowiedzi, na przykład w tekście nr 3 z końca XV w. czytamy:

Ja grzeszny człowiek spowiadam się Bogu wszechmogącemu, pannie Maryjej i matuchnie jego, świętemu Pietru, świętemu Pawłu i wszyćkim świętym, i tobie kapłanie w miasto Boga ustawiony mych wszyćkich grzechow wiadomych i niewiadomych, com się jich dopuścił od mego porodzenia aż do dzisiejszego dnia (ibid.: 124).

Zasadnicza część tekstu to wyznanie grzechów, czyli, jak pisze K. Pisarkowa, samokrytyczny donos grzesznika na siebie samego (ibid.: 11). Kolejne kategorie grzechów są wprowadzane za pomocą formuły z czasownikiem performatywnym, na przykład w spowiedzi nr 1 spowiadamy się Bogu naszemu miłemu, w spowiedzi nr 3 dawam się winien. Ta część tekstu ma strukturę addytywną (Wojtak 2019: 105), przyjmuje formę wyliczenia pod asercją (Wojtak 2007b: 108) popełnionych grzechów. I tak: w ośmiu tekstach (na dziewięć zachowanych dokumentów) penitent spowiada się z grzechów pięciu zmysłów oraz z siedmiu grzechów śmiertelnych (dziś to tzw. grzechy główne), w dalszej kolejności z niespełnienia sześciu lub siedmiu uczynków miłosiernych (dziś tzw. grzechy zaniedbania) i z nieprzestrzegania dekalogu. W trzech spowiedziach penitent uznaje się winnym z dwunastu członków wiary chrześcijańskiej - chodzi o rozpowszechnioną w średniowieczu listę dwunastu grzechów, odtworzoną w XX w. przez Cyrille’a Vogela na podstawie pism nowotestamentalnych i tekstów ojców apostolskich. Na tej liście znalazły się: nieczystość, zabójstwo, bałwochwalstwo, magia, chciwość, kradzież, zawiść, kłamstwo, złość, pycha, niestałość i głupota oraz pijaństwo i nieumiarkowanie (Vogel 1982: 14-15). Najbardziej szczegółowy jest schemat spowiedzi dziewiątej, który jest prezentem od spowiednika. Otwiera go następujące przypisanie:

Najmiłościwsza krolewno, nie raczy wasza miłość waszej miłości kapła<na > a bogomodlce niedostojnego zapominać i s łaski waszej miłości nie wypuszczać, a racz wasza miłość ten dar malućki wdzięcznie przyjąć, boć jest barzo potrzebny zbawieniu i pożyteczny (Pisarkowa 2012: 132).

Adresatką dedykacji i zarazem beneficjentką „książeczki do spowiedzi” - jak ją nazwał w 1898 r. wydawca, Lucjan Malinowski (Zabytek: 1) - jest bliżej nieznana 
królewna Jadwiga ${ }^{6}$. Oprócz standardowego zestawu grzechów penitentka uznaje się winną: $z$ dziewięci cudzych grzechow, $z$ ośmiora błogosławieństwa (o które nie dbała), ze trzech cnot boskich albo bogomownych, to jest wiary, nadzieje i łaski, wreszcie ze trzech cnot zawiesistych, to jest na ktorych ${ }^{7}$ żywot człowieczy ma się obracać (roztropności, sprawiedliwości, stałości albo mężności) (Pisarkowa 2012: 135-136).

Formuła finalna zawiera prośbę skierowaną do odbiorców spowiedzi (w tym do ojca duchownego) o rozgrzeszenie, czyli o uwolnienie od wszystkich grzechów. Oto koda spowiedzi $\mathrm{nr} 2 \mathrm{z}$ początku XV w.: „[...] i proszę tworca wszemogącego w Trocy jedynego i miły Matki Boże, i wszech świętych, i ciebie, occze duchowny, by mie raczył rozdrzeszyć mych wszech grzechow wiadomych i niewiadomych, Amen" (ibid.: 124).

Według K. Pisarkowej przytoczone przykłady staropolskich spowiedzi należy traktować jako teksty docelowe swoistego wewnątrzjęzykowego przekładu $\mathrm{z}$ wewnętrznego języka wyjściowego, który zapewne nie tylko W. Benjamin, ale i niejeden duchowny uzna za uniwersalny język prawdy (ibid.: 121). Jak pisała szwajcarska mistyczka Adrienne von Speyr, „[...] swoim grzechom trzeba się przyglądać tak długo, aż staną się całkowicie oczywiste - same grzechy i ich okoliczności, to, co je poprzedziło, oraz następstwa. [...] Trzeba więc widzieć swoje grzechy tak ostro, jak to tylko jest możliwe, i wystawiać je na przenikliwe światło prawdy" (von Speyr 1998: 163-164). Właśnie prawda, dążenie do poznania prawdy o sobie jest tym, co może łączyć rachunek sumienia i spowiedź z autobiografią. Przypomnijmy: Philippe Lejeune, który stworzył podwaliny teorii autobiografii i wyznaczył kierunki refleksji nad nią, widział w autobiografii utwór referencjalny. Nadawca tekstu autobiograficznego zawiera z odbiorcą nie tylko pakt autobiograficzny, ale i referencjalny sprowadzony do zasady: „Obiecuję mówić całą prawdę i tylko prawdę” (Lejeune 1975: 42). Również Gérard Genette (1991) uznawał autobiografię za jeden z gatunków faktu, jej autor bowiem bierze odpowiedzialność za autentyczność asercji w swojej wypowiedzi (Tutak 2003: 17). Badania rozmaitych form autobiograficznych, które przeprowadziłam, świadczą o tym, że rachunkowi sumienia pojmowanemu w duchowości ignacjańskiej jako examen conscientiae, to jest badanie świadomości, i spowiedzi traktowanej jako confessio, czyli wyznanie grzechów, najbliższa jest ta odmiana autobiografii, którą określa się mianem solilokwium augustiańskie ${ }^{8}$. W tradycji augustiańskiej cechami inwariantnymi solilokwium są: dialog (względnie monolog) udramatyzowany, pragnienie poznania prawdy (w szczególności o sobie samym), Bóg jako dawca natchnienia, adresat i świadek „rozmowy”, pokora wobec Niego, samotność jako warunek skuteczności rozmyślań (Kulczycka 2013: 172). Oczywiście zarówno rachunek sumienia, jak i solilokwium wykluczają takie postawy, jak ego-

6 Być może chodzi o Jadwigę Jagiellonkę, córkę Zygmunta I Starego i Barbary Zapolyi, późniejszą elektorową brandenburską.

7 Tak w: Zabytek: 11, w: Pisarkowa 2012: 136 - najktorych.

8 O podziale na nurt augustiański i antyaugustiański w tradycji solilokwiowej por.: Kulczycka 2013. 
tyzm czy koncentrowanie uwagi podmiotu tylko na sobie, ponieważ badanie własnego sumienia ma na celu wyższe dobro, wykraczające poza dobro partykularne, mianowicie otwarcie się na Boga, na drugiego człowieka oraz na komunię Kościoła.

W czasie sympozjum poświęconego prof. K. Pisarkowej 9 kwietnia 2021 r. w cyklu „Przypomnienia i inspiracje” na Wydziale Polonistyki Uniwersytetu Jagiellońskiego zwracano uwagę na wiele ważnych prac Badaczki, wręcz fundamentalnych dla polskiej lingwistyki, jak Składnia rozmowy telefonicznej (Pisarkowa 1975a) i Wyliczanki polskie (Pisarkowa 1975b), Historia składni języka polskiego (Pisarkowa 1984), Język według Junga. O czytaniu intencji (Pisarkowa 1994), Pragmatyka przekładu. Przypadki poetyckie (Pisarkowa 1998) i wiele innych. Do tej listy warto włączyć Rachunek sumienia jako zadanie tłumacza, który - jak czytamy w nocie wydawniczej jest dziełem niedokończonym. Świadczy jednak o tym, że prof. K. Pisarkową żywo interesowały zagadnienia z pogranicza teolingwistyki i lingwistyki tekstu i że także w tym zakresie Jej badania mogą inspirować, mogą zachęcać do stawiania kolejnych pytań i do poszukiwania odpowiedzi na nie.

\section{Literatura}

Benjamin W., 1923/2011, Zadanie tłumacza, „Literatura na Świecie” nr 5-6, s. 27-41.

Bobrowski I. (red.), 2003, Anabasis. Prace ofiarowane Profesor Krystynie Pisarkowej, Kraków.

BT: Biblia Tysiąclecia. Pismo Święte Starego i Nowego Testamentu w przekładzie z języków oryginalnych, oprac. zespół polskich biblistów pod red. Benedyktynów Tynieckich, Poznań 1965 .

Genette G., 1991, Récit fictionnel, récit factuel, [w:] idem, Fiction et diction, „Poétique”, Paris, s. 65-94.

INGARDEN R., 1988, O dziele literackim. Badania z pogranicza ontologii, teorii języka i filozofii literatury, wyd. 2, „Dzieła filozoficzne”, Warszawa.

KKK: Katechizm Kościoła Katolickiego, [on-line:] www.katechizm.opoka.org.pl.

KulCzyCKA D., 2013, Czym jest soliloquium? W kregu refleksji teoretycznoliterackiej, „Białostockie Studia Literaturoznawcze" nr 4, s. 171-186, https://doi.org/10.1529o/bsl.2013.04.12.

Laвосна J., 2012, Pragmatyczne mechanizmy składni języka mówionego, „Slavia Occidentalis" 69, s. 139-145.

Lejeune P., 1975, Pakt autobiograficzny, „Teksty” nr 5, s. 31-49.

Pisarkowa K., 1975a, Składnia rozmowy telefonicznej, „Prace Instytutu Języka Polskiego”, nr 5, Wrocław.

PisArkowa K., 1975b, Wyliczanki polskie, Kraków.

Pisarkowa K., 1984, Historia składni języka polskiego, „Prace Instytutu Języka Polskiego”, nr 52, Wrocław.

Pisarkowa K., 1994, Język według Junga. O czytaniu intencji, „Nauka dla Wszystkich”, nr 466, Kraków.

Pisarkowa K., 1998, Pragmatyka przekładu. Przypadki poetyckie, „Prace Instytutu Języka Polskiego", nr 106, Kraków. 
PIsArkowa K., 2002, Rachunek sumienia jako zadanie tłumacza, [w:] A. Krasnowolska, B. Mękarska, A. Zaborski (red.), Języki orientalne w przekładzie, „Prace Komisji Orientalistycznej - Polska Akademia Nauk. Oddział w Krakowie”, nr 24, s. 57-66.

PISARKowa K., 2012, Rachunek sumienia jako zadanie tłumacza, Kraków.

Speyr A. von, 1998, Spowiedź, Poznań.

Tutak K., 200o, Problemy opisu składniowego współczesnych tekstów literackich i publicystycznych na przykładzie wybranych typów zdań podrzędnie złożonych, "Język Polski” LXXX, s. 56-62.

TutaK K., 2003, Leksykalne nieczasownikowe wykładniki modalności epistemicznej w autobiografiach, Kraków.

Vogel C., 1982, Le pécheur et la pénitence dans l'Église ancienne, Paris.

WARDA-RADYS L., 2009, Kilka uwag na temat rachunku sumienia dla dzieci, „Język - Szkoła - Religia” t. 4, s. 390-402.

Wielki słownik języka polskiego PAN. Geneza, koncepcja, zasady opracowania, praca zbiorowa, red. P. Żmigrodzki, M. Bańko, B. Batko-Tokarz, J. Bobrowski, A. Czelakowska, M. Grochowski, R. Przybylska, J. Waniakowa, K. Węgrzynek, Kraków 2018.

Wilkoń A., 2001, Gatunki pierwotne i wtórne w perspektywie historycznej i współczesnej, „ER(R)GO. Teoria - Literatura - Kultura” nr 2 (3), s. 75-80.

Wојтак M., 2007a, Rachunek sumienia - analiza genologiczna, [w:] P. Bortkiewicz, S. Mikołajczak, M. Rybka (red.), Język religijny dawniej i dziś. Materiały z konferencji, Poznań, 24-26 kwietnia 2006. 3, „Biblioteczka Poznańskich Studiów Polonistycznych Serii Językoznawczej", nr 36, s. 289-299.

WojtAк M., 2007b, Świat wartości nakreślony w rachunku sumienia, [w:] J. Mazur, A. Małyska, K. Sobstyl (red.), Człowiek wobec wyzwań współczesności. Upadek wartości czy walka o wartość?, „Język, Kultura, Społeczeństwo”, Lublin, s. 104-115.

WojtAк M., 2019, Do Boga..., o Bogu..., przed Bogiem... Gatunki przekazu religijnego w analizie filologicznej, „Teolingwistyka”, nr 15, Tarnów.

WSJP PAN: P. Żmigrodzki (red.), Wielki słownik języka polskiego PAN, [on-line:] www. wsjp.pl.

ZAвYTEK: Zabytek języka polskiego z początku wieku XVI, z rękopisu Biblioteki Uniwersytetu w Erlangen, wyd. L. Malinowski, Kraków 1898.

\section{On Rachunek sumienia jako zadanie tłumacza \\ [Examination of Conscience as a Translator's Task] by Krystyna Pisarkowa Abstract}

The author of the article tries to reconstruct the way in which Krystyna Pisarkowa perceived confession and examination of conscience. Pisarkowa discussed those forms of confessing one's sins in a series of lectures, in an article of 2002, and in a book published two years after her death. The main message of these works is the connection between the examination of conscience and translation according to the approach of Walter Benjamin. In the opinion of Pisarkowa, examination of conscience is a complex act of thought and internal speech that needs to be translated into a natural language. Also, Pisarkowa takes into account the second dimension of updating the examination of conscience, which is related to functioning of a certain genre in religious discourse. She provides some examples of old Polish confessions and she analyses them in terms of textology, which deserves our special attention. 